\title{
Element Sukses Pelaksanaan E-Government Dalam Penanggulangan Kemiskinan Di Dinas Sosial Kota Pekanbaru
}

\author{
Diva Cantika ${ }^{1}$, Harapan Tua RFS ${ }^{2}$ \\ ${ }^{1,2}$ Program Studi Ilmu Administrasi Publik, Fakultas Ilmu Sosial dan Ilmu Politik, \\ Universitas Riau \\ Email : $\underline{\text { divacantika19@gmail.com }}{ }^{1}, \underline{\text { harapan.tua@lecturer.unri.ac.id }}{ }^{2}$ \\ Dikirim : 16 April 2021 | Direvisi : 02 Juni 2021 | Diterima : 14 Juni 2021
}

\begin{abstract}
ABSTRAK
Penelitian ini bertujuan untuk menganalisis pelaksanaan e-government di Dinas Sosial Kota Pekanbaru dalam percepatan penanggulangan kemiskinan di Kota Pekanbaru. Penelitian ini merupakan penelitian kualitatif dengan pendekatan deskriptif. Informan penelitian terdiri dari 3 informan dinas terkait dan 3 informan masyarakat. Teori yang digunakan dalam penelitian yaitu teori elemen sukses pelaksanaan e-government oleh Indrajit dalam (Suaedi \& Wardiyanto 2010) yang terdiri dari Elemen Support, Capacity dan Value. Support element merupakan dukungan dari pejabat politik seperti undang-undang, visi-misi serta sosialisasi. Capacity element merupakan ketersediaan sumberdaya infrastuktur, sumberdaya manusia dan sumberdaya finansial. Value element merupakan manfaat yang dirasakan dengan adanya aplikasi. Hasil penelitian menunjukan dalam pelaksanaan e-government melalui aplikasi Sitanjak Makin Mantap di Dinas Sosial Kota Pekanbaru dalam rangka percepatan penanggulangan kemiskinan masih belum berjalan dengan optimal. Elemen sukses sudah dilaksanakan, namun masih terdapat kendala yang perlu di perbaiki yaitu kegiatan sosialisasi yang tidak berjalan secara berkelanjutan dan menyeluruh di setiap pemerintah kecamatan dan kelurahan serta jaringan internet yang belum maksimal.
\end{abstract}

Kata Kunci: Pelayanan Publik; E-government; Penanggulangan Kemiskinan

\begin{abstract}
Penelitian ini bertujuan untuk menganalisis pelaksanaan e-government di Dinas Sosial Kota Pekanbaru dalam percepatan penanggulangan kemiskinan di Kota Pekanbaru. Penelitian ini merupakan penelitian kualitatif dengan pendekatan deskriptif. Informan penelitian terdiri dari 3 informan dinas terkait dan 3 informan masyarakat. Teori yang digunakan dalam penelitian yaitu teori elemen sukses pelaksanaan e-government oleh Indrajit dalam (Suaedi \& Wardiyanto 2010) yang terdiri dari Elemen Support, Capacity dan Value. Support element merupakan dukungan dari pejabat politik seperti undang-undang, visi-misi serta sosialisasi. Capacity element merupakan ketersediaan sumberdaya infrastuktur, sumberdaya manusia dan sumberdaya finansial. Value element merupakan manfaat yang dirasakan dengan adanya aplikasi. Hasil penelitian menunjukan dalam pelaksanaan e-government melalui aplikasi Sitanjak Makin Mantap di Dinas Sosial Kota Pekanbaru dalam rangka percepatan penanggulangan kemiskinan masih belum berjalan dengan optimal. Elemen sukses sudah
\end{abstract}


dilaksanakan, namun masih terdapat kendala yang perlu di perbaiki yaitu kegiatan sosialisasi yang tidak berjalan secara berkelanjutan dan menyeluruh di setiap pemerintah kecamatan dan kelurahan serta jaringan internet yang belum maksimal.

Keywords: Public Service; E-government; Poverty Reduction

\section{PENDAHULUAN}

Seiring dengan berkembangnya teknologi informasi, segala kegiatan sudah semakin maju termasuk proses pelayanan publik di sektor pemerintahan. Pelayanan publik terus bertransformasi guna menciptakan pelayanan yang efeksien dan efektif dan terus berkembang seiring dengan perkambangan zaman. Pelayanan publik terus bertransformasi sesuai dengan kebutuhan zaman yang semakin modern. Paradigma administrasi publik kelasik (old public administration) 1887-1987 menurut Thoha dalam Syafri (2012:193) inti dari administrasi public klasik yaitu jasa pelayanan terbatas hanya di instansi pemerintah saja, pelayanan secara tradisional, proses pelayanan yang diberikan sangat tertutup, pelayanan sangat memperhatikan garis hirarki dan diawasi oleh pejabat dari hirarki atas organisasi.

Paradigma New Publik Management (NPM) 1990-2000, Pasolong ( 2011:142) melihat NPM sebagai pelayanan publik yang diberikan kepada masyarakat yang menggunakan mekanisme pasar yang berorientasi pada pelanggan (customer). NPM berorientasi pada peningkatan pelayanan yang efektif, efesien dan produktivitas namun kurang memperhatikan keadilan sosial masyarakat. Paradigma New Publik Service (NPS) 2000-sekarang, pergeseran government menjadi governane manjadi langkah dalam mendemokrasikan administrasi publik. Dalam pemberian pelayanan kepada masyarakat tidak hanya terbatas pada instansi pemerintah namun juga berkolaborasi dengan swasta dan masayrakat. Sehingga hasil dari kebijakan dan pelayanan publik merupakan dialog dari nilai-nilai yang disetujui bersama.

E-Government atau pemerintahan elektronik merupakan bentuk penyelenggaraan pemerintahan yang memanfaatkan teknologi informasi dalam penyelenggaraan pemerintahannya. Semua sistem sudah terdigitalisasi yang memungkinkan terintegrasinya pemerintah, swasta dan masyarakat sehingga dapat berpartisipasi aktif dalam proses penyelenggaraan pemerintahan. Menurut Indrajit dalam Pratiwi \& Muslihudin (2018:24), EGovernment adalah penggunaan teknologi informasi yang digunakan untuk memudahkan kepentingan publik yang bertujuan untuk menyelenggarakan kepentingan pemerintahan yang berbasis elektronik dalam rangka meningkatkan kualitas layanan publik.

E-Government mempermudahkan pemberian layanan publik dalam penyampaian informasi dan pembangunan nasional dan diharapkan agar kita mampu menghadapi perubahan dan mampu memanfaatkan teknologi informasi dengan baik sesuai dengan kebijakan yang dibuat oleh Pemerintah tertuang dalam Undang-Undang Nomor 19 Tahun 2016 perubahan dari Undang-Undang Nomor 11 Tahun 2008 tentang Informasi dan Transaksi Elektronik (Pratiwi \& Muslihudin, 2018:22). Tidak hanya memberi kemudahan dalam pelayanan publik, pelaksanaan konsep e-government dilakukan dalam rangka optimalisasi pelayanan publik. Optimalisasi pelayanan publik menurut Indri dan Hayat dalam Buku Manajemen Pelayanan Publik Hayat (2017:49) adalah memberikan pelayanan secara professional dan berkualitas yang mempunyai implikasi positif terhadap kepuasan masyarakat. Profesionalitas pelayanan 
publik ditunjang oleh sikap dan perilaku dalam pemberian pelayanan. Sumberdaya manusia menjadi indikator penting dalam pelayanan publik.

E-Government merupakan perkembangan baru yang meningkatkan pelayanan publik berdasarkan penggunaan teknologi informasi dan komunikasi, sehingga menjadikan pelayanan publik lebih transparan, bertanggung jawab, efektif dan efisien, Haeruddin \& Ikbal (2019:73). Namun, pelaksanaan e-government di Indonesia yang masih pada tahap interaksi belum dapat mentrasformasi pelayanan publik menjadi lebih baik. Walaupun pemerintah sudah menyediakan sarana komunikasi baik dalam bantuk grafis, chatting, word processor maupun mail yang sudah disediakan di setiap website pemerintahan, namun masih belum dapat dimanfaatkan dengan baik untuk sarana komunikasi eksternal. Masih terdapat hambatan atau tantangan dalam implementasi e-government di Indonesia diantaranya yaitu kapasitasi sumberdaya manusia, ketersediaan sarana teknologi informasi dan organisasi, Arifah (2020:33).

Tidak hanya memperbaiki kualitas pelayanan publik, E-Government juga mampu mensupport kinerja pemerintahan dalam rangka percepatan penanggulangan kemiskinan. Manurut Kurnia \& Pradana (2016:1) kemiskinan adalah kondisi masyarakat yang memiliki ketidak mampuan dalam memenuhi kebutuhan dasarnya yaitu makanan, pakaian, tempat tinggal, kesehatan dan pendidikan. Kemiskinan ini dapat disebabkan karena kelangkaan sumber pemenuh kebutuhan dasar atau sulitnya mendapatkan akses kesehatan dan pendidikan. Hal ini juga telah dijelaskan dalam Undang-Undang Nomor 13 Tahun 2013 tentang Penanganan Fakir Miskin. Indonesia sendiri masih berkutat pada penyelesaian masalah kemiskinan dimana berdasarkan data yang di rilis oleh Badan Pusat Statistik pada bulan Maret 2020, jumlah penduduk miskin (penduduk dengan pengeluaran per kapita per bulan di bawah garis kemiskinan) di Indonesia mencapai 26,42 juta jiwa atau 9,78\%. Banyak inovasi yang dilakukan dalam mendukung percepatan penanggulangan kemiskinan di Indonesia salah satunya dengan memanfaatkan teknologi informasi atau e-government.

Dinas Sosial Kota Pekanbaru merupakan salah satu dinas yang menggunakan konsep $e$ government dalam percepatan penanggulangan kemiskinan. Berdasarkan Peraturan Walikota Pekanbaru Nomor 107 Tahun 2016 bab IV bagian keempat tentang Tugas dan Fungsi EGovernment bahwa pemerintah memiliki tugas dalam penyiapan bahan perumusan, pelaksanaan kebijakan di bidang infrastruktur dan teknologi informatika, pengembangan aplikasi dan sistem informasi serta tata kelola E-Government. Pelaksanaan e-government dalam penanggulangan kemiskinan juga mengacu pada Peraturan Presiden nomor 166 tahun 2014, pemerintah mengeluarkan program Pemuktahiran Basis Data Terpadu (PBDT) yang merupakan kegiatan nasional yang tujuannya untuk memastikan Basis Data Terpadu (BDT) sebagai komponen utama dalam penetapan sasaran program penanggulangan kemiskinan di Indonesia.

Menanggapi urgensi dari penyediaan basis data di daerah dan dalam menindak lanjuti program tersebut, Dinas Sosial Kota Pekanbaru membangun suatu sistem aplikasi berbasis website yang memberikan layanan pengaduan kemiskinan bertajuk Sitanjak Makin Mantap (Sistem Terpadu Layanan Jangkauan Masyarakat Miskin yang Mudah, Aman, Nyaman, Tepat, Akuntabel dan Profesional). Aplikasi Sitanjak Makin Mantap mengedepankan masyarakat miskin di bidang pendidikan, kesehatan dan sosial ekonomi. Masyarakat dapat melakukan 
pengaduan melalui aplikasi, dan data tersebut menjadi bahan acuan dalam pengambilan kebijakan percepatan penanggulangan kemiskinan di Kota Pekanbaru. berikut merupakan jumlah pengaduan dan penanganan di aplikasi Sitanjak Makin Mantap.

Tabel 1. Jumlah Pengaduan dan Penanganan di Aplikasi Sitanjak Makin Mantap

\begin{tabular}{|l|l|l|l|l|}
\hline No & Tahun & $\begin{array}{l}\text { Jumlah } \\
\text { Pengaduan }\end{array}$ & $\begin{array}{l}\text { Jumlah } \\
\text { Penanganan }\end{array}$ & $\begin{array}{l}\text { Persentase } \\
(\%)\end{array}$ \\
\hline 1. & 2018 & 45.832 & 25.995 & $57 \%$ \\
\hline 2. & 2019 & 22.964 & 1.585 & $6.90 \%$ \\
\hline 3. & 2020 & 19.281 & 3.213 & $16.66 \%$ \\
\hline
\end{tabular}

Sumber: Dinas Sosial Kota Pekanbaru, 2020.

Dari data di atas menunjukkan jumlah penanganan yang lebih kecil dari pengaduan, hal ini karena orang-orang yang diberi penanganan merupakan masyarakat miskin yang namanya tercantum dalam Data Terpadu Kesejahteraan Sosial (DTKS). Orang yang namanya tidak tercantum DTKS tidak akan diberi penanganan. Apabila masyarakat tersebut dalam kondisi miskin namun belum tercatat dalam DTKS maka dapat mengajukan permohonan DTKS melalui mekanisme musyawarah kelurahan tempat tinggal setempat. Pengoperasian aplikasi Sitanjak Makin Mantap diharapkan dapat mengurangi jumlah kemiskinan di Kota Pekanbaru. Tercatat angka Kemiskinan di Kota Pekanbaru tahun 2019 tercatat sebanyak 2,25\% dengan jumlah penduduk miskin sebesar 28,60 ribu jiwa. Garis kemiskinan pada tahun 2019 sebesar 516.368 rupiah.

Pelaksanaan aplikasi Sitanjak Makin Mantap di Dinas Sosial Kota Pekanbaru tidak secara langsung berpengaruh pada berkurangnya angka kemiskinan di Kota Pekanbaru, namun dengan adanya aplikasi tersebut dapat mensupport kinerja Dinas Sosial Kota Pekanbaru dalam penyediaan database kemiskinan yang terpadu serta diharapkan dapat meningkatkan kualitas pelayanan kepada masyarakat miskin di Kota Pekanbaru. agar pelaksanaan aplikasi Sitanjak Makin Mantap dapat berjalan dengan optimal, maka perlu tersedia sumberdaya-sumberdaya yang mendukung seperti sumberdaya manusia, infrastruktur teknologi, sumberdaya finansial, dukungan dari pejabat publik, sosialisasi dan lain-lain. Maka dari itu, untuk mengidentifikasi sumberdaya yang mendukung pelaksanaan aplikasi Sitanjak Makin Mantap, peneliti melihat menggunakan teori elemen pelaksanaan e-government dimana terdapat tiga elemen yaitu support, capacity dan value menurut Indrajit dalam (Suaedi dan Wardiyanto,2010:81). Permasalahan dalam penelitian ini adalah melihat bagaimana elemen sukses pelaksanaan $e$ government dalam penanggulangan kemiskinan di Dinas Sosial Kota Pekanbaru dan faktor yang mempengaruhi pelayanan e-government dalam penanggulangan kemiskinan di Dinas Sosial Kota Pekanbaru.

\section{METODE PENELITIAN}

Jenis penelitian yang digunakan dalam penelitian ini adalah penelitian kualitatif dengan pendekatan deskriptif. Sugiyono (2016:4) mengartikan metode penelitian kualitatif, yaitu metode penelitian yang didasarkan pada filosofi post-positive untuk mengkaji kondisi bendabenda alam. Dalam hal peneliti adalah instrumen kunci, teknologi pengumpulan data 
didasarkan pada triangulasi / kombinasi, analisis datanya bersifat induktif / kualitatif, dan hasil penelitian lebih menekankan pada makna daripada generalisasi.Teknik pengumpulan data melalui proses Wawancara, Observasi dan dokumentasi. Dalam hal ini informan yang di wawancarai adalah Kepala Seksi Bidang Pemberdayaan Sosial dan Penanganan Fakir Miskin, Kepala Seksi Data, Pelaporan dan Pengaduan Masyarakat, Front Office dan Masyarakat.Sumber data di Peroleh melalui 2 sumber yaitu data Primer dan data sekunder. Data primer diperoleh dari hasil wawancara dengan informan penelitian, sedangkan data sekunder diperoleh dari buku, jurnal, laporan dan sumber lainnya. teknik analisis data menggunakan model interaktif dari Hubberman dan Miles (1992) dalam Idrus (2009:147-148) dimana analisis data terdiri atas tiga hal utama, yaitu (1) reduksi data; (2) penyajian data; dan (3) penarikan kesimpulan atau verifikasi.

\section{HASIL DAN PEMBAHASAN \\ Elemen sukses pelaksanaan E-government}

Untuk mengetahui Pelayanan E-government melalui aplikasi Sitanjak Makin Mantap maka penulis menggunakan beberapa indikator pelayanan E-government menurut Indrajit 2010 yaitu

\section{Support Element}

Dalam pelaksanaan e-government dalam penanggulangan kemiskinan di Dinas Sosial Kota Pekanbaru sangat dibutuhkan adanya dukungan atau political will dimana dalam hal imi yaitu adanya dukungan baik berupa kebijakan, disepakatinya kerangka e-government, dukunan finansial dan sosialisasi. Dalam pelaksanaan aplikasi Sitanjak Makin Mantap di Dinas Sosial Kota Pekanbaru, dukungan yang diberikan Pemerintah Kota Pekanbaru yaitu disepakatinya kerangka e-government dan disahkannya aplikasi tersebut oleh Walikota Pekanbaru kala itu yaitu Bapak H.Firdaus ST MT bersama pemerintah kecamatan dan kelurahan Kota Pekanbaru di Kecamatan Tenayan Raya.

Gambar 1. Launching Aplikasi Sitanjak oleh Walikota Pekanbaru dan OPD lainnya di

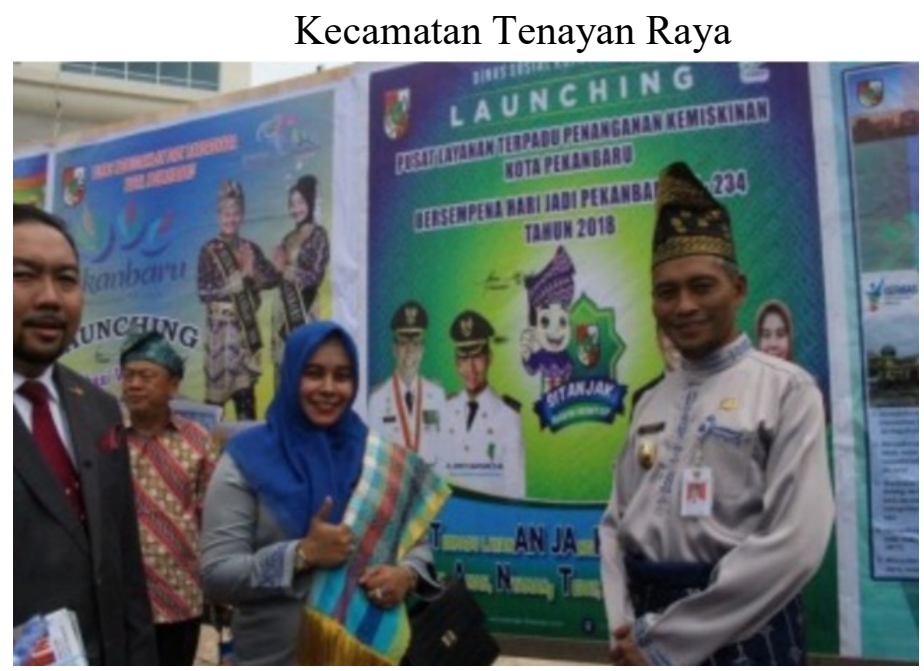

Sumber: Dinas Sosial Kota Pekanbaru, 2020. 
Dukungan juga berbentuk kebijakan yang mengatur pelaksanaan e-government dalam pelayanan publik yaitu Peraturan Menteri Sosial Nomor 15 Tahun 2018 tentang penanganan kemiskinan yang sudah berbasis aplikasi. Kemudian ada Peraturan Presiden nomor 166 tahun 2014 tentang program Pemuktahiran Basis Data Terpadu (PBDT) yang merupakan kegiatan nasional yang tujuannya untuk memastikan Basis Data Terpadu (BDT) sebagai komponen utama dalam penetapan sasaran program penanggulangan kemiskinan di Indonesia.

Adanya dukungan finansial diberikan oleh Kementerian Sosial pada tahun 2018 berupa bantuan anggaran kepada Dinas Sosial Kota Pekanbaru untuk memenuhi kebutuhan serta sarana dan prasarana yang menunjang pelaksanaan aplikasi Sitanjak Makin Mantap. Untuk meningkatkan efektivitas aplikasi Sitanjak Makin Mantap, Dinas Sosial Kota Pekanbaru bekerjasama dengan Kementerian Sosial, Dinas Pendidikan Kota Pekanbaru, Dinas Kesehatan Kota Pekanbaru dan Dinas Kependudukan dan Pencatatan Sipil Kota Pekanbaru guna menindak lanjuti kebutuhan pengaduan masyarakat miskin dan pengecekan serta verifikasi data kependudukan. Sosialisasi aplikasi Sitanjak Makin Mantap juga telah dilaksanakan di setiap kecamatan yang ada di Kota Pekanbaru, namun pelaksanaannya hanya di awal tahun saja sehingga masih terdapat masyarakat tidak paham penggunaan aplikasi dan yang tidak tahu keberadaan aplikasi Sitanjak Makin Mantap.

\section{Capacity Element}

Capacity element terdiri atas tiga bagian yaitu ketersediaan sumberdaya manusia, sumberdaya, sumberdaya finansial dan sumberdaya infrastruktur. Dalam pelaksanaan aplikasi Sitanjak Makin Mantap, sumberdaya manusia dibagi menjadi beberapa seksi dan petugas. Hal ini dimaksud untuk memperjelas tugas dan tanggung jawab masing-masing dan membentuk arah koordinasi antar bagian. Berikut merupakan pembagian pengelola aplikasi Sitanjak Makin Mantap di Dinas Sosial Kota Pekanbaru:

Tabel 2. Petugas Pengelola Aplikasi Sitanjak Makin Mantap di Dinas Sosial Kota Pekanbaru

\begin{tabular}{|l|l|l|}
\hline No & Sertifikasi & Jumlah Petugas \\
\hline 1. & Seksi Data Pelaporan dan Pengaduan Masyarakat & 1 \\
\hline 2. & Seksi Pendidikan & 1 \\
\hline 3. & Seksi Kesehatan & 1 \\
\hline 4. & Seksi Sosial Ekonomi & 1 \\
\hline 5. & Operator Aplikasi & 1 \\
\hline 6. & Relawan Pendamping & 15 \\
\hline Jumlah & 20 \\
\hline
\end{tabular}

Sumber: Dinas Sosial Kota Pekanbaru, 2021.

Untuk meningkatkan kemampuan sumberdaya manusianya, sumberdaya manusia yang ada juga diberi bimbingan teknis (bimtek) oleh Kementerian Sosial dan diikuti oleh Kepala Dinas, beberapa Kepala Seksi dan Operator aplikasi di tahun 2017 dan kemudian ilmu yang didapat dibagikan kepada sumberdaya manusia lainnya yang ada di Dinas Sosial Kota Pekanbaru. Sumberdaya infrastuktur sangat penting dalam pelaksanaan aplikasi Sitanjak 
Makin Mantap. Sarana prasarana teknologi informasi sangat mendukung pelaksanaan aplikasi yang berbasis elektronik. Adapun sarana prasarana pengoperasial aplikasi Sitanjak antara lain.

Tabel 3. Sarana dan Prasarana aplikasi Sitanjak Makin Mantap

\begin{tabular}{|l|l|l|}
\hline No & Jenis Sarana Prasarana & Unit \\
\hline 1. & Komputer Asus & 11 \\
\hline 2. & Printer & 8 \\
\hline 3. & Wifi & 2 \\
\hline 4. & Mobil Sitanjak & 1 \\
\hline 5. & Ambulance & 1 \\
\hline 6. & Genset besar & 1 \\
\hline
\end{tabular}

Sumber: Dinas Sosial Kota Pekanbaru, 2021.

Komputer, printer dan Wifi digunakan untuk pengaksesan aplikasi, pengolahan dan penginputan data, pengintegrasian data, penyimpanan data dan lain-lain. Mobil Sitanjak dan Ambulace digunakan untuk kegiatan penjangkauan apabila terdapat peristiwa mendesak. Genset besar disediakan apabila mati listrik yang mengakibatkan akses masuk aplikasi terhambat.

\section{Value Element}

Value element berkaitan dengan nilai dan manfaat yang diberikan dengan adanya aplikasi Sitanjak Makin Mantap di Dinas Sosial Kota Pekanbaru. Bagi penyedia pelayanan, Aplikasi Sitanjak Makin Mantap membantu birokrat dalam pendataan masyarakat miskin dan penyediaan basis data terpadu. Hal ini karena pelaksanaan pelayanan secara konvensional harus dibuat dalam bentuk hardcopy, softcopy, dan fotocopy, sedangkan pelayanan online hanya akan menghasilkan satu data terpadu dan dapat dicetak sewaktu-waktu bila diperlukan. Data pengaduan membantu birokrat dalam pengambilan kebijakan, dengan semakin mudahnya proses pengaduan atau permohonan bantuan masyarakat maka proses pengambilan keputusan semakin cepat pula dan membantu dalam percepatan penanggulangan kemiskinan yang ada di Kota Pekanbaru.

Sebagai masyarakat tentu mendapatkan kemudahan karena pelayanan secara online membuat kita tidak perlu datang ke Dinas untuk membuat permohonan PKH, KIS, dan KIP. Kita bisa membuka aplikasinya dimana saja dan kapan saja selagi ada handphone dan jaringan yang mendukung. Namun hal ini terkendala dengan masih kurang mendukungnya sarana bagi masyarakat untuk mengakses aplikasi, yaitu tidak tersedianya handphone, jaringan yang mendukung ditempat tinggal tersebut serta pola pikir masyarakat yang masih tradisional dan memilih untuk melakukan pengaduan offline.

\section{Faktor yang mempengaruhi pelayanan e-government}

Dalam pelayanan e-government di Dinas Sosial Kota Pekanbaru terdapat faktor yang mempengaruhi pelayanan untuk mengetahui apakah pelayanan berjalan optimal atau tidak. Terdapat dua faktor yaitu. 
a. Faktor Pendukung; Faktor yang sangat mendukung pelaksanaan aplikasi Sitanjak Makin Mantap di Dinas Sosial Kota Pekanbaru terdiri dari dua yaitu sumberdaya manusia dan sarana prasana. Sumberdaya manusia yang tersedia memiliki tugas dan tanggung jawab yang jelas, hal itu didukung dengan adanya pembagian bagian berupa seksi dan petugas sehingga memperjelas tugas dan wewenang masing-masing dan memperjelas arah koordinasi. Dan yang terpenting adalah sumberdaya manusia yang ada di Dinas Sosial Kota Pekanbaru mampu dan paham menggunakan sarana prasana teknologi informasi dan komunikasi seperti komputer dan smartphone. Sarana-prasana merupakan faktor yang sangat mendukung pelaksanaan aplikasi Sitanjak Makin Mantap setelah sumberdaya manusia. Untuk merasakan perbedaan dari pelayanan penanggulangan kemiskinan secara tradisional dan modern tentu berkaitan dengan sarana dan prasarana yang disediakan. Dalam pelaksanaan aplikasi Sitanjak Makin Mantap di Dinas Sosial Kota Pekanbaru diantaranya komputer, printer, wifi, mobil Sitanjak Makin Mantap dan Ambulance.

b. Faktor Penghambat; Faktor penghambat pelaksanaan aplikasi Sitanjak Makin Mantap terdiri menjadi dua yaitu sosialisasi dan gangguan jaringan. Masih kurang maksimalnya sosialisasi yang diberikan membuat masih banyak masyarakat yang tidak mengetahui keberadaan dan tidak memahami penggunaan aplikasi Sitanjak Makin Mantap di Dinas Sosial Kota Pekanbaru. gangguan jaringan juga sangat menghambat proses pelayanan yang berbasis elektronik. Gangguan jaringan yang sewaktu-waktu dapat muncul membuat pelayanan menjadi kurang maksimal.

Hasil penelitian sebelumnya yang mirip terkait pelaksanaan e-government (Suradi \& Irmayani, 2018) menunjukan bahwa pelaksanaan e-government dalam penanggulangan kemiskinan berbasis keterpaduan data di Kabupaten Serang belum berjalan dengan baik, hal ini dikarenakan tidak adanya koordinasi yang baik dengan Organisasi Perangkat Daerah (OPD) yang menyelenggarakan program penanggulangan kemiskinan. Setiap OPD memiliki data kemiskinannya sendiri-sendiri, sehingga pelaksanaan e-government dalam penanggulangan kemiskinan di Kabupaten Serang tidak optimal selama lima tahun terakhir. Penelitian berbeda yang dilakukan oleh (Santoso et al., 2016) menunjukkan bahwa dalam penerapan e-government melalui Sistem Informasi Keluarga Miskin (Simgakin) di Badan Perencanaan Pembangunan Daerah Kota Semarang belum berjalan optimal, hal ini dikarenakan kurang terpenuhinya sumberdaya manusia yang profesional di bidang IT. Hal ini menghambat proses pengambilan keputusan dalam pemberian fasilitas SPP kepada siswa miskin di Kabupaten Semarang.

Penelitian (Larasati, 2019) menujukan terdapat 8 elemen sukses e-government dalam implementasi sistem informasi aplikasi mobile pajak daerah (Sampade) Kota Malang. Elemen sukses tersebut yaitu Political Environment, Leadership, Planning. Stakeholders. Transparancy, Budgets, Technology dan Innovation. Dari hasil analisis, pelaksanaan elemen sukses tersebut tidak berjalan dengan baik hal ini karena beberapa faktor yaitu dalam pelaksanaan aplikasi masih terkesan setengah hati karena tidak adanya keberlanjutan perencanaan, buruknya koordinasi dengan stakeholder, kurangnya sosialisasi, serta tingkat keamanan yang rendah masih ditemui peretasan sistem. Penelitian (Safitri et al., 2019) menunjukan terdapat 10 faktor sukses implementasi e-government di pemerintahan Kota Malang yaitu keterlibatan stakeholder, perencanaan, pengguna, pelatihan, usabilitas sistem, kampanye, pembiayaan, kompetensi sdm, kepemimpinan, dan koordinasi. Namun pelaksaanya 
belum optimal karena terdapat beberapa hambatan yaitu kemampuan sumberdaya manusia yang terbatas, keterbatasan jaringan internet di Instansi pemerintahan, tidak fleksibelnya Struktur Organisasi dan Tata Kerja (SOTK), dan belum adanya regulasi yang tegas.

Penelitian ini berkontribusi pada literatur dimana menunjukkan elemen-elemen sukses yang diperlukan dalam pelaksanaan e-government dalam tata kelola pemerintahan yang memberikan berbagai keuntungan baik peningkatan kualitas pelayanan publik, efesiensi dan efektivitas kinerja pelayanan serta mampu menyelesaikan permasalahan sosial salah satunya kemiskinan. Dalam implementasi e-government dibutuhkan elemen-elemen yang bila di sederhanakan terdiri dari tiga elemen yaitu Support, Capacity dan Value. Pada indikator support merupakan dukungan yang diberikan oleh pejabat publik yaitu adanya kebijakan atau payung hukum yang tegas, visi-misi yang mendukung implementasi e-government, serta sosialisasi guna meningkatkan keikut sertaan masyarakat terhadap konsep e-government yang dibangun. Capacity merupakan ketersediaan sumberdaya yang meliputi sumberdaya manusia, sumberdaya infrastuktur dan sumberdaya finansial. Value merupakan manfaat atau keuntungan yang dirasakan dengan kehadiran e-government.

Pelaksanaan e-government di Dinas Sosial Kota Pekanbaru berupa aplikasi Sitanjak Makin Mantap merupakan inovasi dalam rangka mensupport kinerja dinas dalam penyediaan database masyarakat miskin yang menjadi acuan pengambilan kebijakan penanggulangan kemiskinan bagi stakeholder yang berkepentingan. Dilihat melalui teori tiga elemen sukses di atas, ditemukan bahwa dalam pelaksanaan e-government di Dinas Sosial Kota Pekanbaru sudah adanya payung hukum yang tegas dari pemerintah pusat maupun daerah yaitu Undang-Undang Nomor 19 Tahun 2016, Peraturan Presiden nomor 166 tahun 2014 tentang program Pemuktahiran Basis Data Terpadu (PBDT) dan Peraturan Walikota Pekanbaru Nomor 107 Tahun 2016 bab IV bagian keempat tentang Tugas dan Fungsi E-Government. Sosialisasi sudah dilaksanakan setiap awal tahun di setiap Kecamatan dan Kelurahan. Pelaksanaan aplikasi Sitanjak Makin Mantap juga mendukung terwujudnya visi misi Kota Pekanbaru yaitu Smart City yang Madani. Sumberdaya manusia memiliki kompetensi yang baik serta terdapat pembagian tugas yang jelas yang memudahkan proses koordinasi. Tersedianya saranaprasarana baik software maupun hardware seperti komputer, wifi, internet, mobil Sitanjak dan Genset. Adanya bantuan anggaran yang diberikan Kementerian Sosial di tahun pertama pengoperasial aplikasi, kemudian ditahun selanjutnya Dinas Sosial mengganggarkan sendiri dalam Dokumen Pelaksanaan Anggaran (DPA).

\section{KESIMPULAN}

Pelayanan e-government dalam penanggulangan kemiskinan di Dinas Sosial Kota Pekanbaru dapat disimpulkan belum berjalan optimal. Hal ini dapat dilihat dengan masih adanya penghambat yang berupa sosialisasi dan gangguan jaringan yang membuat pelaksanaan aplikasi Sitanjak Makin Mantap di Dinas Sosial Kota Pekanbaru belum maksimal. Oleh sebab itu saran untuk penelitian ini yaitu perlu adanya konsistensi dan pemerataan dalam proses sosialisasi serta inovasi proses sosialisasi yang dapat dilakukan dalam bentuk tradisional seperti pemasangan banner di kantor atau dijalan umum maupun secara modern melalui media online. Dan untuk gangguan jaringan dapat melakukan perbaikan sistem jaringan atau server 
dengan menambah kecepatan jaringan internet/wifi atau menyediakan jaringan internet lain yang dapat digunakan bila jaringan utama terganggu.

\section{DAFTAR PUSTAKA}

Arifah, U. (2020). Transformasi Birokrasi Melalui E-Government. Jurnal Cakrawala: Studi Manajemen Pendidikan Islam Dan Studi, 4(2), 30-41.

Haeruddin, \& Ikbal, M. (2019). Optimalisasi Pelayanan Publik Melalui Pemanfaatan Teknologi Informasi di Desa Timoreng Panua Kabupaten Sidenreng Rappang. JURNAL OF GOVERNMENT - JOG (Kajian Manajemen Pemerintahan \& Otonomi Daerah), 5, 69-88.

Hayat. (2017). Manajemen Pelayanan Publik (R. Nugroho (ed.); 1st ed.). Jakarta: PT RajaGrafindo Persada.

Kurnia, A., \& Pradana, A. (2016). Pembuatan Aplikasi Berbasis Crowdsourcing dalam Upaya Penanggulangan Penduduk Miskin. Jurnal Informatika Dan Multimedia, 08(01), 1-9. http://ojs.poltek-kediri.ac.id/index.php/JIM/article/view/26

Larasati, D. C. (2019). Analisis Elemen Sukses E-Government Dalam Implementasi Sistem Informasi Aplikasi Mobile Pajak Daerah (Sampade) Kota Malang. Conference on Innovation and Application of Science and Technology (CIASTECH 2019, Ciastech, 93100 .

Pasolong, H. (2011). Teori Administrasi Publik (3rd ed.). Bandung: Alfabeta.

Pratiwi, E., \& Muslihudin, M. (2018). Implementasi E-Goverment Sebagai Upaya Peningkatan Potensi Desa Di Desa Bumirejo Menggunakan Web Mobile. Technology Acceptance Model, 9(1), 22-29. https://doi.org/10.1136/oem.52.9.587

Safitri, N., Sugiarti, Rachmawati, Surani, D. N., Fahmadhani, A., Wulandari, S., Riza, M., Kurniawan, A., \& Nugraha, J. T. (2019). Kajian Faktor Sukses Implementasi EGovernment Studi Kasus Di Pemerintah Kota Magelang. Jurnal Mahasiswa Administrasi Negara, 03(03), 22-32.

Santoso, F., Djumiarti, T., \& Rihandoyo, R. (2016). Analisis Sistem Informasi Manajemen Keluarga Miskin (SIMGAKIN) dalam Proses Pengambilan Keputusan Kebijakan Dinas Pendidikan dengan Kegiatan Pemberian Fasilitasi Sumbangan Pembinaan Pendidikan (SPP) Siswa Miskin yang Bersekolah Swasta di Kota Semarang. Journal of Public Policy and Management Review, 5(2), 903-921.

Sugiyono. (2016). Metode Penelitian Kuantitatif, Kualitatif dan R\&D (23rd ed.). Bandung: Alfabeta.

Suradi, S., \& Irmayani, N. R. (2018). Penanggulangan Kemiskinan Berbasis Keterpaduan Data Di Kota Semarang. Sosio Konsepsia, 8(1), 1-13. https://doi.org/10.33007/ska.v8i1.1568

Syafri, W. (2012). Studi tentang Administrasi Publik (Y. S. Hayati (ed.); 1st ed.). Jakarta: Erlangga.

Yunita, N. P., \& Aprianto, R. D. (2018). Kondisi Terkini Perkembangan Pelaksanaan EGovernment Di Indonesia: Analisis Website. Seminar Nasional Teknologi Informasi Dan Komunikasi, 2018(Sentika), 329-336. 